\title{
KONDISI OPTIMUM ADSORPSI ARANG HAYATI DARI KULIT PISANG RAJA (Musa X paradisiaca L.) TERHADAP LOGAM TIMBAL (Pb) DAN TEMBAGA (Cu)
}

\author{
The Optimum Condition of Biocharcoal from Banana Peel (Musa X paradisiaca L.) on \\ Adsorption of Lead (Pb) and Copper (Cu) Metals
}

\author{
*Iren S. A. Tanggebono, Vanny M. A. Tiwow dan Minarni R. Jura \\ Pendidikan Kimia/FKIP - Universitas Tadulako, Palu - Indonesia 94118 \\ Received 2 March 2018, Revised 3 April 2018, Accepted 3 May 2018
}

\begin{abstract}
This study aimed to determine the optimum condition of biocharcoal from banana peel on adsorption of lead $\mathrm{Pb})$ and copper $(\mathrm{Cu})$ metals based on the variation of weights and biocharcoal contact times. Banana peel used in this research were taken from Sidondo III the village, Kec. Sigi Biromaru, Kab. Sigi, Central Sulawesi. To determine absorbed metals in biocharcoal banana peel was measured by a spectrophotometer spectroDirect. The results showed that the optimum weight of adsorption lead ion was $80 \mathrm{mg}$ and copper ion was $40 \mathrm{mg}$ with each percentage adsorption of $73.91 \%$ and $21.23 \%$, respectively. The optimum time to adsorb lead and copper ions was 90 minutes with the percentage adsorption of $89.13 \%$ for lead ion and $25.86 \%$ for copper ion.
\end{abstract}

Keywords: Biocharcoal, plantain banana peel, adsorption, lead, copper, and spectrophotometer spectroDirect.

\section{Pendahuluan}

Buah pisang tidak asing lagi bagi masyarakat karena merupakan makanan yang sangat digemari oleh semua lapisan masyarakat baik di daerah perkotaan maupun didaerah pedesaan. Selain sebagai makanan selingan pisang juga merupakan komoditi eksport yang bermutu tinggi seperti yang dilakukan negara-negara penghasil pisang yang besar. Dari semua manfaat pisang yang paling banyak diketahui oleh masyarakat umumnya hanya sebatas buah, daun dan batang saja. Padahal sejatinya masih banyak lagi bagian dari pisang yang sangat berguna. Salah satunya adalah kulit pisang, namun kulit pisang dianggap limbah sehingga jarang dimanfaatkan oleh masyarakat, contohnya masyarakat di kota Palu Sulawesi Tengah. Banyak penjual pisang goreng atau olahan pisang lain yang hanya membuang kulit pisangnya begitu saja, dimana hal tersebut dapat menimbulkan masalah lingkungan, limbah kulit pisang dianggap tidak memiliki nilai ekonomis (Manurung, 1996).

Selain sampah organik yang disebabkan oleh berbagai sumber buangan seperti kulit pisang, berbagai pencemaran juga banyak terjadi akibat limbah industri. Sebagian besar industri belum memiliki sistem pengolahan limbah untuk logam berat dan cenderung membuang limbahnya ke lingkungan dan menimbulkan pencemaran (Dermatas \& Meng, 2004). Hal ini berpengaruh pada kesuburan tanaman, kesehatan hewan dan manusia. Pencemaran ini terjadi pada perairan, udara dan tanah (Filda, 2010).

*Correspondence

Iren S. A. Tanggebono

Program Studi Pendidikan Kimia, Fakultas Keguruan dan

Ilmu Pendidikan, Universitas Tadulako

e-mail: Tanggebonoirensuryani@gmail.com

Published by Universitas Tadulako 2018
Beberapa penelitian tentang efek paparan logam berat pada hewan telah banyak dilaporkan, paparan logam berat dalam waktu yang lebih lama akan memicu peningkatan ROS (reactive oxygen species) sehingga memicu kematian sel sedang pada tumbuhan dapat menghambat pengambilan (uptake) nutrisi, menghambat aktivitas enzim, termasuk sistem antioksidan organisme hidup (John, dkk., 2009).

Timbal adalah logam yang mendapat perhatian khusus karena sifatnya yang toksik (beracun) terhadap manusia. Timbal dapat masuk ke dalam tubuh melalui konsumsi makanan, minuman, udara, air, serta debu yang tercemar timbal. Walaupun jumlah logam timbal yang terserap dalam tubuh hanya sedikit namun dapat memberikan efek racun terhadap fungsi organ tubuh. Setelah terakumulasi, organ-organ yang menjadi sasaran keracunan timbal adalah sistem saraf, ginjal, reproduksi, endokrin, dan jantung. Setiap bagian yang menyerap racun timbal akan memperlihatkan efek yang berbeda-beda (Radyawati, 2011).

Logam tembaga sebagai logam esensial, sangat diperlukan dalam kelangsungan hidup organisme perairan. Logam tersebut berperan dalam proses metabolisme makhluk hidup sebagai metal koenzim. Kebutuhan akan logam tembaga bervariasi untuk masing-masing individu, dan jika melebihi batas yang telah ditentukan logam tembaga akan memberikan dampak negatif terhadap individu tersebut. Tembaga dalam tubuh manusia, terdistribusi secara umum sepanjang jaringan, dalam konsentrasi yang cukup tinggi akan menyebabkan gangguan pada liver, ginjal, sumsum tulang, otak dan rambut. Liver adalah tempat yang utama bagi tembaga (Lisnawati, 2011).

Beberapa metode yang dapat digunakan untuk menurunkan konsentrasi ion logam dalam limbah 
cair diantaranya adalah pengendapan, penukar ion, dengan menggunakan resin, filtrasi dan adsorpsi (Tangio, 2013). Diantara metode-metode tersebut, adsorpsi merupakan metode yang paling umum dipakai karena memiliki konsep yang lebih sederhana dan dapat diregenerasi serta ekonomis (Darmayanti, dkk., 2012).

Penelitian tentang pemanfaatan bahan-bahan organik yang dijadikan sebagai bahan penyerap telah banyak dilakukan, bahan-bahan organik tersebut diubah menjadi arang hayati untuk mengadsorpi logam berat sehingga dapat mengurangi pencemaran dan penyakit yang diakibatkan logam-logam berat tersebut (Kawasaki, dkk., 2006). Kulit pisang memiliki kemampuan dalam mengikat ion logam berat, dikarenakan dalam kulit pisang terdapat berbagai gugus fungsi yang berperan sebagai gugus aktif seperti gugus hidroksil $(-\mathrm{OH})$, gugus karboksilat $(-\mathrm{COOH})$ dan gugus amina $\left(-\mathrm{NH}_{3}\right)$ (Castro, et al., 2011).

Tulisan ini bertujuan untuk menentukan kondisi optimum adsorpsi arang hayati dari kulit pisang raja (musa $x$ paradisiaca L.) terhadap logam timbal $(\mathrm{Pb})$ dan tembaga $(\mathrm{Cu})$ dari larutannya berdasarkan variasi berat arang hayati dan waktu kontak.

\section{Metode}

\section{Alat dan Baban}

Alat yang digunakan pada penelitian ini yaitu pipet tetes, cawan porselin, gelas kimia, gelas ukur, oven, ayakan 70 mesh, neraca digital, shaker, labu ukur, lumpang dan alu, tanur, pH meter Eutech Instrumens, erlenmeyer, batang pengaduk, rak dan tabung reaksi, kertas aluminium foil, botol semprot, desikator, dan Spektrofotometer SpektroDirect (Lovibond).

Bahan yang digunakan yaitu kulit pisang raja, aquades, larutan sampel $\mathrm{Pb}\left(\mathrm{NO}_{3}\right)_{2}($ Merck), larutan sampel $\mathrm{CuSO}_{4} \cdot 5 \mathrm{H}_{2} \mathrm{O}$ (Merck), larutan $\mathrm{NH}_{4} \mathrm{OH}$ (Merck), larutan $\mathrm{HCl}$ (Merck), tablet reagen Cooper/Zinc LR (Lovibond), reagen Lead test (Merck) dan kertas saring Whatman 41.

\section{Pembuatan arang hayati kulit pisang raja}

Sampel kulit pisang raja yang bersih dipotong kecil-kecil lalu dikeringkan di bawah sinar matahari selama \pm 5 hari. Selanjutnya sampel kulit pisang raja dikeringkan kembali menggunakan oven dengan suhu $60{ }^{\circ} \mathrm{C}$ selama 24 jam lalu didinginkan pada suhu kamar. Kemudian sampel kulit pisang raja dimasukkan ke dalam tanur pada suhu $300{ }^{\circ} \mathrm{C}$ dengan kadar oksigen yang rendah sampai terbentuk arang. Setelah itu dihaluskan dan diayak menggunakan ayakan 70 mesh, arang yang terbentuk disimpan ditempat yang kering dan tertutup.

\section{Karakterisasi arang hayati}

\section{Kadar air}

10 gram arang hayati ditimbang dengan teliti di dalam cawan yang telah diketahui beratnya. Kemudian dikeringkan dalam oven dengan temperatur $105{ }^{\circ} \mathrm{C}$ selama kurang lebih 3 jam. Setelah itu dimasukkan ke dalam desikator dan selanjutnya ditimbang. Diulangi perlakuan yang sama sampai diperoleh berat konstan. Kadar air dihitung dengan rumus sebagai berikut (Susilawati, dkk., 2015):

$$
\text { Kadar air }=\frac{(a-b)}{a} \times 100 \%
$$

dimana $\mathrm{a}=$ berat karbon mula-mula $(\mathrm{g}) ; \mathrm{b}=$ berat karbon setelah dikeringkan

\section{Kadar abu}

10 gram arang hayati ditimbang dengan teliti di dalam cawan yang telah diketahui beratnya. Selanjutnya, biocharcoal dikeringkan selama 3 jam pada temperatur $105^{\circ} \mathrm{C}$, kemudian diabukan pada temperatur $500{ }^{\circ} \mathrm{C}$ selama 1 jam. Setelah itu didinginkan dalam desikator dan ditimbang. Perlakuan yang sama diulangi sampai diperoleh bobot yang tetap.

Kadar abu dihitung dengan rumus sebagai berikut (Susilawati, dkk., 2015):

$$
\text { Kadar abu }=\frac{\text { Berat Abu }}{\text { Berat Arang }} \times 100 \%
$$

\section{Pengarub variasi berat arang hayati terhadap adsorpsi logam $\mathrm{Pb}$}

$25 \mathrm{~mL}$ larutan $\mathrm{Pb}$ yang telah diatur pHnya sebesar 5 dimasukkan ke dalam 15 buah erlenmeyer yang tersedia. 3 buah erlenmeyer yang berisi larutan $\mathrm{Pb}$ ditambahkan dengan arang hayati kulit pisang raja sebanyak $20 \mathrm{mg}, 3$ erlenmeyer berikutnya dengan $40 \mathrm{mg}$ arang hayati kulit pisang raja, 3 erlenmeyer berikutnya dengan $60 \mathrm{mg}$ arang hayati kulit pisang raja, 3 erlenmeyer berikutnya dengan $80 \mathrm{mg}$ arang hayati kulit pisang raja, dan 3 erlenmeyer berikutnya dengan $100 \mathrm{mg}$ arang hayati pisang raja lalu ditutup dengan kertas aluminium foil dan diikat dengan karet kemudian dishaker selama 60 menit, lalu didiamkan selama 24 jam. Selanjutnya disaring menggunakan kertas saring, filtrat yang diperoleh diukur konsentrasinya menggunakan spektrofotometer spektroDirect.

\section{Pengaruh variasi berat arang hayati terhadap adsorpsi logam $\mathrm{Cu}$}

$25 \mathrm{~mL}$ larutan $\mathrm{Cu}$ yang telah diatur pHnya sebesar 4 dimasukkan ke dalam 15 buah erlenmeyer yang tersedia. 3 buah erlenmeyer yang berisi larutan $\mathrm{Cu}$ ditambahkan dengan arang hayati kulit pisang raja sebanyak $20 \mathrm{mg}$, 3 Erlenmeyer berikutnya dengan $40 \mathrm{mg}$ arang hayati kulit pisang raja, 3 erlenmeyer berikutnya dengan $60 \mathrm{mg}$ arang hayati kulit pisang raja, 3 erlenmeyer berikutnya dengan $80 \mathrm{mg}$ arang hayati kulit pisang raja, dan 3 erlenmeyer berikutnya dengan $100 \mathrm{mg}$ arang hayati pisang raja lalu ditutup dengan kertas aluminium foil dan diikat dengan karet kemudian dishaker selama 60 menit, lalu didiamkan selama 24 jam. Selanjutnya disaring menggunakan kertas saring, filtrat yang diperoleh diukur konsentrasinya menggunakan spektrofotometer spektroDirect. 


\section{Pengaruh variasi waktu kontak terhadap adsorpsi} logam $\mathrm{Pb}$

$25 \mathrm{~mL}$ larutan $\mathrm{Pb}$ dimasukkan ke dalam 12 buah erlenmeyer yang tersedia. Masing-masing erlenmeyer ditambahkan arang hayati kulit pisang raja berdasarkan berat optimum yang diperoleh pada variasi berat arang hayati. Lalu erlenmeyer ditutup dengan kertas aluminium foil dan diikat dengan karet kemudian dishaker selama 60, 90, 120, dan 150 menit lalu didiamkan selama 24 jam. Selanjutnya disaring menggunakan kertas saring, filtrat yang diperoleh diukur konsentrasinya menggunakan spektrofotometer spektroDirect.

\section{Pengaruh Variasi Waktu Kontak terhadap Adsorpsi Logam Cu}

$25 \mathrm{~mL}$ larutan $\mathrm{Cu}$ dimasukkan ke dalam 12 buah erlenmeyer yang tersedia. Masing-masing erlenmeyer ditambahkan arang hayati kulit pisang raja berdasarkan berat optimum yang diperoleh pada variasi berat arang hayati. Lalu erlenmeyer ditutup dengan kertas aluminium foil dan diikat dengan karet kemudian dishaker selama 60 menit, 90 menit, 120 menit, dan 150 menit lalu didiamkan selama 24 jam. Selanjutnya disaring menggunakan kertas saring, filtrat yang diperoleh diukur konsentrasinya menggunakan spektrofotometer spektro Direct.

Data yang diperoleh dari hasil pengukuran konsentrasi logam dengan menggunakan spektrofotometer spektroDirect dianalisis dengan persamaan (Sangkota, 2015) :

\section{Hasil dan Pembahasan}

\section{Karakteristik arang hayati}

Kadar air merupakan salah satu sifat kimia dari arang hayati yang mempengaruhi kualitas arang hayati tersebut. Penetapan kadar air arang hayati bertujuan untuk mengetahui sifat hidroskopis dari arang hayati. Kadar air dari arang hayati kulit pisang raja relatif kecil yaitu 3,3\%. Berdasarkan nilai kadar air arang hayati yang diperoleh, dapat diketahui bahwa arang hayati kulit pisang raja bersifat hidroskopis dan memiliki kemampuan untuk mengadsorbsi gas atau cairan lain. Makin kecil kadar air yang dimiliki, kualitas arang hayati makin baik. Pada umumnya, arang hayati selalu mengandung air walaupun dalam jumlah yang rendah, sebab struktur ikatan dari atom C penyusunnya sulit untuk melepaskan semua airnya (Pari, 1992).

Parameter lain yang mempengaruhi kualitas arang hayati selain kadar air adalah kadar abu. Adapun kadar abu yang diperoleh adalah 18,2\%. Tingginya rendahnya kadar abu yang dihasilkan dapat mempengaruhi daya adsorbsi arang hayati. Semakin tinggi kadar abu, maka daya adsorbsi biocharcoal semakin lemah. Hal ini disebabkan karena pori-pori biocharcoal terisi oleh mineralmineral logam seperti $\mathrm{K}, \mathrm{Na}, \mathrm{Ca}$ dan $\mathrm{Mg}$ (Lebu, 2009).
Variasi berat arang hayati terhadap adsorpsi logam timbal dan tembaga

Berat arang hayati kulit pisang raja yang pada penelitian bertindak sebagai adsorben, merupakan faktor yang sangat mempengaruhi proses adsorpsi logam timbal dan tembaga. Hal ini disebabkan karena berat arang hayati menunjukan jumlah partikel adsorben yang dapat menyerap ion logam pada konsentrasi tertentu. Variasi berat arang hayati yang digunakan adalah $20,40,60,80$, dan $100 \mathrm{mg}$. Proses pengukuran dilakukan pada pada $\mathrm{pH}$ yang sama, yaitu untuk logam timbal pada $\mathrm{pH}$ 5, dan logam tembaga pada $\mathrm{pH}$ 4. Penggunaan nilai $\mathrm{pH}$ tersebut didasarkan pada nilai maksimum kelarutan logam timbal dan tembaga dalam aquades berdasarkan diagram Pourbaix.

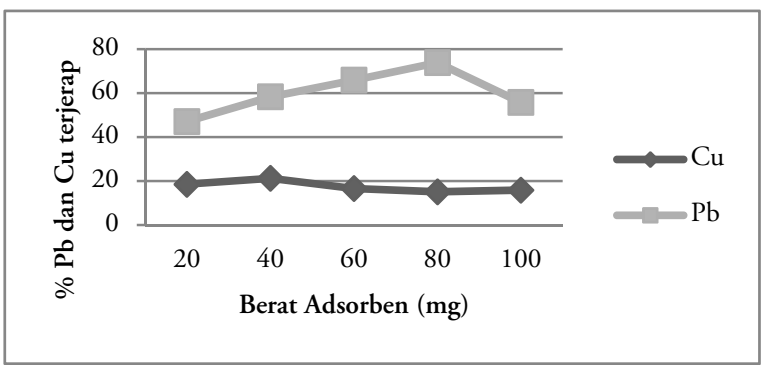

Gambar 1 Kurva hubungan antara berat arang hayati $(\mathrm{mg})$ terhadap persen logam timbal dan tembaga terjerap

Dari data yang disajikan pada Gambar 1 yaitu pada data yang menunjukkan penjerapan logam timbal (warna putih) terlihat bahwa berat adsorben meningkat dari $20 \mathrm{mg}$ sampai $100 \mathrm{mg}$, namun tidak menyebabkan persentase logam timbal yang terjerap meningkat. Berdasarkan data tersebut terlihat bahwa terjadi peningkatan adsorpsi logam timbal pada berat arang hayati $20-80 \mathrm{mg}$ dengan persentase jerapan berturut-turut adalah $47,10 \%$, $58,33 \%, 65.94 \%$, dan 73,91\%, dengan kapasitas jerapan berturut-turut adalah $1,62 \mathrm{mg} / \mathrm{g}, 1,01$ $\mathrm{mg} / \mathrm{g}, 0,76 \mathrm{mg} / \mathrm{g}$, dan $0,64 \mathrm{mg} / \mathrm{g}$. Namun pada berat adsorben $80 \mathrm{mg}$ ke $100 \mathrm{mg}$ jerapannya relatif menurun dengan persentase jerapan menjadi $55,79 \%$ dan kapasitas jerapan adalah 0,38 mg/g.

Data yang disajikan pada Gambar 1 untuk data penjerapan logam tembaga (berwarna hitam) dengan variasi berat adsorben yang digunakan sama dengan berat adsorben yang digunakan pada logam timbal yaitu meningkat dari $20 \mathrm{mg}$ sampai $100 \mathrm{mg}$. Hal inipun tidak menyebabkan persentase logam tembaga yang terjerap terus meningkat, namun ada sedikit perbedaan keduanya. Dari data terlihat pada berat arang hayati $(20-40) \mathrm{mg}$ terjadi peningkatan adsorpsi logam tembaga dengan persentase jerapan $18,53 \%$ dan $21,23 \%$ dengan kapasitas jerapan $0,60 \mathrm{mg} / \mathrm{g}$ dan $0,34 \mathrm{mg} / \mathrm{g}$. Selanjutnya terjadi penurunan adsorpsi logam tembaga pada berat arang hayati $60 \mathrm{mg}$ dan $80 \mathrm{mg}$, dengan persentase sebesar $16,60 \%$ dan $15,05 \%$ dengan kapasitas jerapan $0,18 \mathrm{mg} / \mathrm{g}$ dan 0,10 $\mathrm{mg} / \mathrm{g}$. Kemudian terjadi kenaikan kembali pada berat adsorben $100 \mathrm{mg}$ namun tidak melebihi persentasi penjerapan berat adsorben $40 \mathrm{mg}$ yaitu 
dengan persentase jerapan $15.83 \%$ dengan kapasitas jerapan $0,10 \mathrm{mg} / \mathrm{g}$.

Jerapan logam timbal meningkat dari berat adsorben $20 \mathrm{mg}$ sampai $80 \mathrm{mg}$, sedangkan jerapan logam tembaga meningkat dari berat adsroben 20 $\mathrm{mg}$ sampai $40 \mathrm{mg}$. Berdasarkan hal tersebut menunjukkan bertambahnya jumlah adsorben yang berinteraksi dengan logam timbal dan tembaga menyebabkan terjadinya peningkatan jerapan, dimana luas permukaan adsorben untuk menjerap logam meningkat sehingga jumlah logam yang terikat akan lebih banyak. Selain itu, hal ini juga terjadi karena pengaruh kerapatan sel adsorben dalam larutan sehingga menghasilkan interaksi yang cukup efektif antara pusat aktif dinding sel adsorben dengan ion logam timbal dan tembaga, sehingga semakin banyak zat penjerap maka semakin banyak pusat aktif biocharcoal yang bereaksi. Oleh sebab itu, pada saat jumlah adsorben diperbesar, perbandingan tersebut tidak lagi dipenuhi, sehingga berpengaruh terhadap aktivitas penjerapan ion logam timbal dan tembaga oleh adsorben (Radyawati, 2011).

Jerapan logam timbal cenderung menurun pada berat arang hayati $100 \mathrm{mg}$, sedangkan jerapan logam tembaga menurun pada berat arang hayati $60 \mathrm{mg}$ sampai $100 \mathrm{mg}$. Hal ini dapat terjadi karena permukaan adsorben telah berada dalam keadaan jenuh oleh ion-ion logam sehingga peningkatan berat adsorben relatif tidak meningkatkan penjerapan ion logam oleh adsorben (Djufri, 2009).

Peningkatan jumlah logam timbal dan tembaga tidak proporsional dengan berat adsorben mengindikasikan bahwa peningkatan berat adsorben relatif tidak mempengaruhi jumlah timbal dan tembaga yang terjerap oleh adsorben. Dari data tersebut diperoleh bahwa kondisi optimum pada penjerapan logam timbal terjadi pada berat adsorben sebanyak $80 \mathrm{mg}$, dengan persentase jerapan $73,91 \%$ dan kapasitas jerapan $0,64 \mathrm{mg} / \mathrm{g}$. Sedangkan pada logam tembaga kondisi optimum penjerapan logamnya terjadi pada berat adsorben sebanyak $40 \mathrm{mg}$, dengan persentase jerapan $15,83 \%$ dan kapasitas jerapan $0,34 \mathrm{mg} / \mathrm{g}$. Sehingga akan digunakan untuk keperluan variabel penelitian selanjutnya, agar data yang diperoleh menggambarkan efektivitas jerapan adsorben yang optimum (Radyawati, 2011).

\section{Variasi waktu kontak arang hayati terhadap adsorpsi logam timbal dan tembaga}

Penelitian tentang pengaruh waktu ini dilakukan untuk mengetahui informasi mengenai salah satu parameter yang mempengaruhi adsorpsi logam berat yaitu waktu kontak, serta untuk memperoleh informasi tentang waktu kontak yang diperlukan untuk mencapai kesetimbangan (adsorpsi maksimum) logam oleh adsorben.

Waktu kontak merupakan salah satu faktor yang mempengaruhi proses adsorpsi, karena melalui proses kontak penjerapan terjadi sebagai akibat dari interaksi fisik (adhesi) antara adsorbat dan adsorben. Penentuan waktu kontak optimum pada adsorpsi logam timbal dan tembaga menggunakan adsorben arang hayati kulit pisang raja dilakukan pada waktu kontak 60 menit, 90 menit, 120 menit dan 150 menit. Penentuan waktu optimum ini bertujuan untuk mengetahui waktu kontak optimum dari adsorpsi larutan timbal dan tembaga oleh adsorben arang hayati pisang raja.

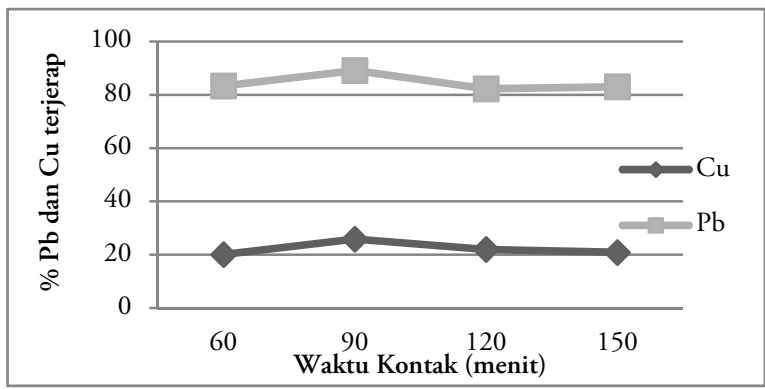

Gambar 2 Kurva hubungan antara waktu kontak (menit) terhadap persen logam timbal dan tembaga terjerap

Hasil penelitian untuk pengaruh waktu kontak dari larutan logam timbal dan tembaga terhadap kemampuan adsorpsi arang hayati kulit pisang raja seperti yang terlihat dalam Gambar 2, yang memperlihatkan bahwa adsorpsi logam timbal dan logam tembaga dipengaruhi oleh waktu kontak antara larutan dan sampel arang hayati namun peningkatan persentase penjerapan tidak terlalu besar.

Dari data yang disajikan pada Gambar 2 menunjukkan penjerapan logam timbal (warna putih) menunjukan bahwa waktu kontak yang optimum pada adsorpsi logam timbal adalah pada 80 menit. Persentase penjerapan logam timbal oleh arang hayati pisang raja pada masing-masing variasi waktu adalah, pada 60 menit sebesar 83,33\% dengan kapasitas jerapan sebesar $0,72 \mathrm{mg} / \mathrm{g}, 90$ menit sebesar $89,13 \%$ dengan kapasitas jerapan $0,77 \mathrm{mg} / \mathrm{g}$, pada 120 menit sebesar $82,24 \%$ dengan kapasitas jerapan sebesar $0,71 \mathrm{mg} / \mathrm{g}$, dan pada waktu kontak 150 menit sebesar 82,97\% dengan kapasitas jerapan $0,71 \mathrm{mg} / \mathrm{g}$.

Data yang disajikan pada Gambar 2 untuk data penjerapan logam tembaga (berwarna hitam) dengan variasi waktu kontak yang digunakan sama dengan variasi waktu yang digunakan pada logam timbal diperoleh waktu kontak yang optimum pada adsorpsi logam tembaga adalah pada 80 menit. Persentase penjerapan logam timbal oleh arang hayati pisang raja pada masing-masing variasi waktu adalah, pada 60 menit sebesar 20,07\% dengan kapasitas jerapan sebesar 0,32 mg, 90 menit sebesar $25,86 \%$ dengan kapasitas jerapan sebesar $0,42 \mathrm{mg}$, pada 120 menit sebesar 22,00\% dengan kapasitas jerapan sebesar $0,36 \mathrm{mg}$, dan pada waktu kontak 150 menit sebesar 20,84\% dengan kapasitas jerapan sebesar 0,34 mg.

Rentang waktu 60 sampai 90 menit kemampuan adsorben arang hayati kulit pisang raja dalam mengadsorpsi logam timbal dan tembaga meningkat. Pada jerapan logam timbal 
menurun pada rentang waktu 120 menit dan kembali meningkat namun tidak signifikan pada rentang waktu 150 menit. Sedangkan pada logam tembaga, jerapan logam tembaga menurun pada rentang waktu 120 menit sampai 150 menit. Hal ini menunjukkan waktu optimum yang diperlukan arang hayati kulit pisang raja untuk mengadsorpsi logam timbal dan tembaga yaitu 90 menit dengan persentase jerapan berturut turut $89,13 \%$ dan $25,86 \%$, dan kapasitas jerapan $0,77 \mathrm{mg} / \mathrm{g}$ dan $0,42 \mathrm{mg} / \mathrm{g}$.

Peningkatan daya jerap terjadi karena semakin lama waktu kontak mengakibatkan interaksi antara arang hayati kulit pisang raja dengan ion timbal dan tembaga terjadi secara efektif. Hal itu disebabkan karena semua sisi aktif yang terdapat pada arang hayati kulit pisang raja saling berikatan dengan ion-ion timbal dan ion-ion tembaga dalam larutannya. Selain itu, proses adsorpsi juga dipengaruhi oleh besar kecilnya ukuran adsorben yang digunakan yang menyebabkan luas permukaan sentuhnya relatif besar sehingga kemungkinan terjadinya interaksi yang sangat efektif antara sisi aktif pada adsorben dengan ion logam (Khopkar, 2003).

Efisiensi penjerapan menurun diduga karena terjadi proses desorpsi. Hal ini merupakan fenomena dalam adsorpsi fisika yang menyatakan bahwa proses adsorpsi bersifat reversible (Sukardjo, 1990). Hal ini karena, ikatan lemah yang terjadi antara adsorben dengan ion logam akan lepas kembali ke dalam larutannya karena semakin lama waktu kontak (Lestari, 2010).

Waktu kontak antara ion logam dengan adsorben sangat mempengaruhi daya jerap. Setelah adsorpsi mencapai titik optimum maka selanjutnya akan terjadi proses penguraian yang disebut desorpsi. Kondisi optimum ini disebut dengan keadaan kesetimbangan adsorpsi. Pada waktu kontak adsorpsi yang optimum, kapasitas logam terjerapnya maksimal. Namun setelah melewati titik kesetimbangan tersebut logam tersebut mengalami proses desorpsi, logam terjerapnya kembali berkurang (Dyah, dkk., 2012).

\section{Kesimpulan}

Berat optimum yang diperlukan arang hayati dari kulit pisang raja untuk menjerap logam timbal $\mathrm{Pb})$ adalah sebesar $80 \mathrm{mg}$ dengan persentase jerapan $73.91 \%$ dan berat ion $\mathrm{Pb}$ yang terjerap yaitu $0,64 \mathrm{mg} / \mathrm{g}$. Berat optimum arang hayati dari kulit pisang raja untuk menjerap logam tembaga $(\mathrm{Cu})$ adalah sebesar $40 \mathrm{mg}$ dengan persentase jerapan $21,23 \%$ dan berat ion $\mathrm{Cu}$ yang terjerap yaitu $0,34 \mathrm{mg} / \mathrm{g}$.

Waktu kontak optimum yang diperlukan arang hayati kulit pisang raja untuk menjerap logam timbal $(\mathrm{Pb})$ adalah 90 menit dengan persentase jerapan $89,13 \%$ dan berat ion $\mathrm{Pb}$ yang terjerap yaitu $0,77 \mathrm{mg} / \mathrm{g}$. Waktu kontak optimum yang diperlukan arang hayati kulit pisang raja untuk menjerap logam tembaga $(\mathrm{Cu})$ adalah 90 menit dengan persentase jerapan $25,86 \%$ dan berat ion $\mathrm{Cu}$ yang terjerap yaitu $0,42 \mathrm{mg} / \mathrm{g}$.

\section{Ucapan Terima Kasih}

Penulis mengucapkan terima kasih kepada pihak yang telah membantu penelitian ini, khususnya kepada laboran Laboratorium Kimia Fakultas Keguruan dan Ilmu Pendidikan Universitas Tadulako.

\section{Referensi}

Castro, R. S. D., Caetano, L., Ferreira, G., Padilha, P. M., Saeki, M. J., Zara, L. F., Martines, A. M. A. U. \& Catro, G. R. (2011). Banana peel applied to the solid phase extraction of copper and lead fromm river water: Preconcentration of metal ions with a fruit waste. Journal American Chemical Society, 50, 3446-3451.

Darmayanti, Rahman, N. \& Supriadi. (2012). Adsorpsi timbal $(\mathrm{Pb})$ dan zink (Zn) dari larutan menggunakan arang hayati (bocharcoal) kulit pisang kepok berdasarkan variasi $\mathrm{pH}$. Jurnal Akademika Kimia, 1(4), 159-165.

Dermatas, D. \& Meng, X. (2004). Removal of As, $\mathrm{Cr}$ and $\mathrm{Cd}$ by adsorptive filtration. Global Nest: The International Journal, 6(1), 73-80.

Djufri, H. (2009). Variasi waktu kontak dan berat absorben pada penentuan kapasitas adsorpsi $\mathrm{Cr}$ (VI) menggunakan ampas tahu. Skripsi Sarjana. Palu: FKIP Universitas Tadulako, tidak ditertibkan.

Dyah, K., Susatyo E. B. \& Prasetya, A. T. (2012). Pemanfaatan zeolit abu sekam padi untuk menurunkan kadar ion $\mathrm{Pb}^{2+}$ pada air sumur. Indonesian Journal of Chemical Science, 1(1), 14-19.

Filda. (2010). Pengaruh $p H$ tanah pada penarikan logam kromium dari tanah menggunakan tanaman sawi hijau (Brassica junceae). Skripsi Sarjana. Palu: FKIP Universitas Tadulako, tidak diterbitkan.

Sangkota, V, D, A. (2015). Pengaruh aktivasi kimia arang tanaman eceng gondok (Eichhornia crassipes) terhadap adsorpsi logam timbal (Pb). Skripsi Sarjana. Palu: FKIP Universitas Tadulako, tidak diterbitkan.

John, R., Ahmad, P., Gadgil, K. \& Sharma, S. (2009). Heavy metal toxicity: Effect on plant grownth, biochemical parameters and metal accumulation by brassica juncea 1 . International Jurnal of Plant Production, 3(3), 65-76.

Kawasaki, N., Bun-ei, R., Ogata, F., Nakamura, T., Tanei, S. \& Tanada, S. (2006). Water treatmend technology using carbonaceus material produced from vegetable biomass. Journal of Water and Environment Technology, $4(1), 73-82$.

Khopkar. (2003). Konsep dasar kimia analitik. Jakarta: UI-Press. 
Lebu, M. (2009). Pembuatan arang aktif dari tulang sapi dan aplikasinya pada pemucatan crude palm oil (CPU) Skripsi Sarjana. Palu: FKIP Universitas Tadulako, tidak diterbitkan.

Lestari, S. (2010). Pengaruh berat dan waktu kontak untuk adsorpsi Timbal (II) oleh adsorben dari kulit batang jambu biji (Psidium Guajaval). Jurnal Kimia Mulawarman, 8(1), 710.

Lisnawati. (2011). Kadar tembaga (Cu) dan nikel (Ni) pada tailing buangan pengelolaan emas poboya di daerah ngatabaru palu sulawesi tengah. Skripsi Sarjana. Palu: FKIP Universitas Tadulako, tidak diterbitkan.

Manurung, R. (1996). Pemanfaatan limbah kulit buah pisang sebagai bahan baku pembuatan etanol. Skripsi Sarjana. Palu: FKIP Universitas Tadulako, tidak diterbitkan.
Pari, G. (1992). Pembutan arang aktif dari serbuk gergaji zinkon untuk penjernihan air. Buletin Penelitian Hasil Hutan, 10(5), 141-149.

Radyawati. (2011). Pembuatan biocharcoal dari kulit pisang kepok untuk penyerapan logam timbal $(\mathrm{Pb})$ dan logam seng ( $\mathrm{Zn})$. Skripsi Sarjana. Palu: FKIP Universitas Tadulako, tidak diterbitkan.

Sukardjo. (1990). Kimia anorganik: Cetakan kedua. Jakarta: Rineka Cipta.

Susilawati, N. E., Walanda, D. K. \& Napitupulu, M. (2015). Biocharcoal dari serbuk gergaji kayu cempaka (Elmerrillia ovalis Miq) serta daya adsorpsinya pada zink dan tembaga. Jurnal Akademika Kimia, 4(2), 71-77.

Tangio, J. S. (2013). Adsorpsi logam timbal (Pb) dengan menggunakan biomassa eceng gondok (Eichhorniacrassipes) Jurnal Entropi, 8(1), 501-506. 